\title{
PHARMACOKINETICS AND BIOAVAILABILITY OF DOXYCYCLINE IN FASTED AND NONFASTED BROILER CHICKENS
}

\author{
P. LACZAY*, G. SEMJÉN, J. LEHEL and G. NAGY \\ Department of Pharmacology and Toxicology, Faculty of Veterinary Science, \\ Szent István University, H-1400 Budapest, P.O. Box 2, Hungary
}

(Received July 7, 2000; accepted October 30, 2000)

\begin{abstract}
The pharmacokinetics and the influence of food on the kinetic profile and bioavailability of doxycycline was studied after a single intravenous (i.v.) and oral dose of $10.0 \mathrm{mg} / \mathrm{kg}$ body weight in 7-week-old broiler chickens. Following i.v. administration the drug was rapidly distributed in the body with a distribution half-life of $0.21 \pm 0.01 \mathrm{~h}$. The elimination half-life of $6.78 \pm 0.06 \mathrm{~h}$ was relatively long and resulted from both a low total body clearance of $0.139 \pm 0.007 \mathrm{~L} / \mathrm{h} \cdot \mathrm{kg}$ and a large volume of distribution of $1.36 \pm 0.06 \mathrm{~L} / \mathrm{kg}$. After oral administration to fasted chickens, the absorption of doxycycline was quite fast and substantial as shown by the absorption half-life of $0.39 \pm 0.03 \mathrm{~h}$, the maximal plasma concentration of $4.47 \pm 0.16 \mu \mathrm{g} / \mathrm{mL}$ and the time to reach the $\mathrm{C}_{\max }$ of $1.73 \pm 0.06 \mathrm{~h}$. The distribution and the final elimination of the drug were slower than after i.v. administration. The absolute bioavailability was $73.4 \pm 2.5 \%$. The presence of food in the intestinal tract reduced and extended the absorption $\left(\mathrm{t}_{1 / 2 \mathrm{a}}=1.23 \pm 0.21 \mathrm{~h}\right.$; $\mathrm{C}_{\max }=3.07 \pm 0.23 \mu \mathrm{g} / \mathrm{mL} ; \mathrm{t}_{\max }=3.34 \pm 0.21 \mathrm{~h}$ ). The absolute bioavailability was reduced to $61.1 \% \pm 4.4 \%$.
\end{abstract}

Key words: Doxycycline, pharmacokinetics, bioavailability, chicken, food

Doxycycline is a semisynthetic tetracycline derivative. It is 5 to 10 times more lipid soluble than the traditional tetracyclines, providing marked adva ntages in terms of a more extensive absorption after oral administration, a wider distribution and a greater tissue penetration, a prolonged biological half-life, as well as an enhanced antibacterial activity against several organisms (Aronson, 1980; Shaw and Rubin, 1986). As regards the avian species, the pharmacokine tics and bioavailability of doxycycline have been extensively studied in turkeys (Küng and Wanner, 1994; Santos et al., 1996; Santos et al., 1997). Much less i nformation is available on the pharmacokinetics of the drug in chickens (Anadón et al., 1994), and there are no data on the possible influence of food on these

\footnotetext{
*Present address: Department of Food Hygiene, Faculty of Veterinary Science, Szent István University, H-1400 Budapest, P.O. Box 2, Hungary;

E-mail: placzay@univet.hu; Fax: +36 (1) 478-4155
} 
properties. In turkeys, the bioavailability of doxycycline was dramatically a ffected by the presence of food in the intestinal tract (Santos et al., 1996). In h uman beings and mammals, however, doxycycline absorption was found to be much less affected by food (Welling et al., 1977; Meijer et al., 1993).

The present studies were undertaken to study the pharmacokinetic profile and the influence of food on the pharmacokinetics and bioavailability of doxyc ycline in broiler chickens, after a single i.v. and oral administration, respectively.

\section{Materials and methods}

\section{Animals and housing}

Eighteen healthy 7-week-old Arbor Acres broiler chickens of both sexes were used in the experiment. The animals were purchased from a poultry farm and housed in individual cages in an experimental animal house. The mean body weight $( \pm \mathrm{SD})$ of the birds was $2.04 \pm 0.10 \mathrm{~kg}$. Before the commencement of the experiment the animals were acclimatised for 2 weeks. The room temperature was $20-22{ }^{\circ} \mathrm{C}$ and the relative humidity was maintained at $50-70 \%$. Commercial diet and water were provided ad libitum. The ration did not contain any drug or growth promoter.

\section{Experimental design}

Birds were allotted to three groups with six animals in each. Chickens of Group 1 were given doxycycline intravenously, whereas to Groups 2 and 3 the drug was administered orally, in each case at a dose of $10 \mathrm{mg} / \mathrm{kg}$ body weight on a single occasion. Doxycycline hyclate was dissolved in distilled water to obtain a concentration of $10 \mathrm{mg}$ doxycycline per $\mathrm{mL}$. One $\mathrm{mL}$ solution was injected into the right brachial vein or given directly into the crop for each $\mathrm{kg}$ of body weight. In Groups 1 and 2, food was withheld for $12 \mathrm{~h}$ before dosing until $6 \mathrm{~h}$ after drug administration. In Group 3, the birds were not fasted prior to treatment, and were allowed access to food throughout the experiment.

From chickens of Group 1, blood samples were drawn via a cannula from the left brachial vein into syringes at 0 (pre-dose), 0.08, 0.17, 0.25, 0.5, 1, 2, 4, 6, 8,12 and $24 \mathrm{~h}$ after dosing. In cases of Groups 2 and 3, the sampling times were as follows: $0,0.17,0.33,0.5,1.0,1.5,2,3,4,6,8,10,12$ and $24 \mathrm{~h}$. Plasma sa mples were separated after centrifugation at $5{ }^{\circ} \mathrm{C}$ and $2000 \mathrm{~g}$ for $10 \mathrm{~min}$, and were stored frozen at $-24{ }^{\circ} \mathrm{C}$ until analysed.

\section{Sample analysis}

Plasma doxycycline concentrations were determined by reversed phase high-performance liquid chromatography (HPLC) with UV detection. Briefly, 
the HPLC system was composed of a Hewlett Packard 1090 liquid chromat ograph (Hewlett Packard, Waldbron, Germany) and a reversed phase column ( Lichrosorb RP 18, $5 \mu \mathrm{m}, 250 \times 4 \mathrm{~mm}$, Hewlett Packard). The mobile phase consisted of acetonitrile:methanol:0.02 M oxalic acid:0.02 M Na 2 EDTA (20:15:64:1 [v/v]). The flow rate was $1.0 \mathrm{~mL} / \mathrm{min}$ and the UV detection took place at $345 \mathrm{~nm}$. The determination was performed in two phases: dilution with oxalic acid followed by solid-phase extraction with Sep-Pak C18 cartridge and then reversed phase HPLC measurement. The assay procedure was as follows: $1 \mathrm{~mL}$ of plasma was diluted with $10 \mathrm{~mL}$ of $0.2 \mathrm{M}$ oxalic acid. After centrifugation $(2500 \mathrm{~g}, 10 \mathrm{~min})$ the separated supernatant was passed through a Sep-Pak C18 cartridge. The co 1umn was washed with $2 \mathrm{~mL}$ of bidistilled water and $1 \mathrm{~mL}$ of $10 / 90 \mathrm{v} / \mathrm{v}$ meth anol/ $/ 0.02 \mathrm{M}$ oxalic acid and the investigated compound was eluted with $4 \mathrm{~mL}$ of methanol. The eluent was evaporated under a nitrogen stream at $50{ }^{\circ} \mathrm{C}$ and the residue was dissolved in $0.5 \mathrm{~mL}$ of the mobile phase. Plasma concentrations of doxycycline were quantified against calibration curves of plasma samples spiked with doxycycline reference standard (Sigma, St. Louis, USA).

Linear calibration curves $\left(\mathrm{r}^{2}>0.99\right)$ were obtained in plasma between $0.02-5.0 \mu \mathrm{g} / \mathrm{mL}$. The limit of the detection was $0.010 \mu \mathrm{g} / \mathrm{mL}$, while the quantification limit was $0.020 \mu \mathrm{g} / \mathrm{mL}$. The recovery rates for three different concentr ations $(0.10,0.50$ and $2.00 \mu \mathrm{g} / \mathrm{mL})$ were greater than $80 \%$ and the intra- and interassay coefficients of variation at the same plasma concentrations were less than $10 \%$. The method used was selective for the compound analysed; endogenous interference was not observed on chromatograms.

\section{Pharmacokinetic and statistical analysis of data}

The plasma concentration-time data for each individual bird were analysed by one-compartment and two-compartment open models using the MedUsa (Version 1.6) computer program (Várkonyi, 1983). The absolute bioavailability $\left(\mathrm{F}_{\mathrm{abs}}\right)$ was calculated as the ratio of the individual AUC (Area Under the Co ncentration-Time Curve) values after oral administration to the mean AUC value of the i.v. application. The relative bioavailability $\left(\mathrm{F}_{\mathrm{rel}}\right)$ was obtained as the ratio of the individual AUC after oral administration to nonfasted chickens to the mean AUC after oral application to fasted birds.

Differences in pharmacokinetic data obtained from fasted and nonfasted animals were analysed for statistical significance by the paired Student's $t$-test. Differences of $\mathrm{P}<0.05$ were considered significant. 


\section{Results}

The mean doxycycline plasma concentration-time profiles after a single i.v. dose and a single oral administration to fasted and nonfasted chickens are presented in Figs 1 and 2. As the curves show the plasma concentrations of doxycycline decreased in a bioexponential manner after both administration routes. A good fit of the observed data to a two-compartment open model was obtained. The values of the calculated pharmacokinetic parameters are summ arised in Table 1.

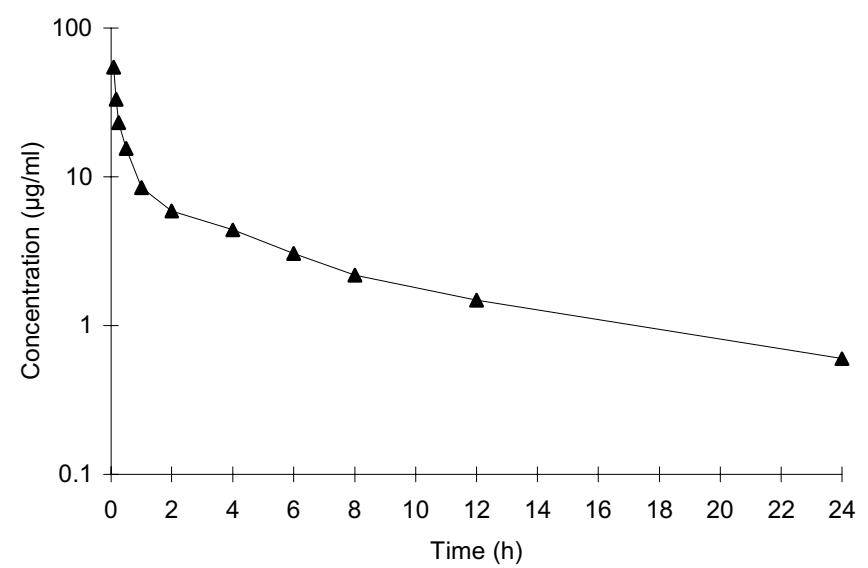

Fig. 1. Mean plasma concentrations of doxycycline after intravenous administration to broiler chickens

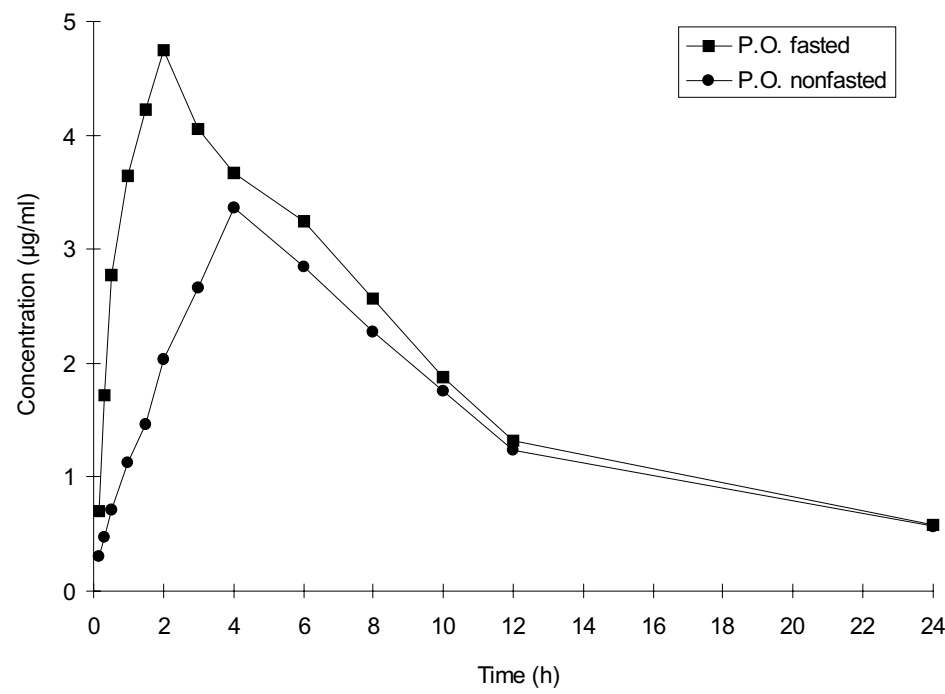

Fig. 2. Mean plasma concentrations of doxycycline after oral administration to fasted and nonfasted broiler chickens 
Table 1

Pharmacokinetic parameters of doxycycline following intravenous dosing and oral administration to fasted and nonfasted broiler chickens

\begin{tabular}{|c|c|c|c|}
\hline \multirow{3}{*}{ Parameter } & \multicolumn{3}{|c|}{ Administration } \\
\hline & \multirow{2}{*}{ Intravenous } & \multicolumn{2}{|c|}{ Oral } \\
\hline & & Fasted & Nonfasted \\
\hline$\alpha\left(\mathrm{h}^{-1}\right)$ & $3.37 \pm 0.18$ & $0.21 \pm 0.02^{*}$ & $0.43 \pm 0.09^{*}$ \\
\hline$\beta\left(h^{-1}\right)$ & $0.10 \pm 0.01$ & $0.09 \pm 0.01$ & $0.08 \pm 0.01$ \\
\hline $\mathrm{K}_{\mathrm{a}}\left(\mathrm{h}^{-1}\right)$ & - & $1.85 \pm 0.16^{*}$ & $0.62 \pm 0.07^{*}$ \\
\hline$t_{1 / 2 a}(h)$ & - & $0.39 \pm 0.03^{*}$ & $1.23 \pm 0.21^{*}$ \\
\hline$t_{1 / 2 \alpha}(h)$ & $0.21 \pm 0.01$ & $3.61 \pm 0.43^{*}$ & $2.18 \pm 0.35^{*}$ \\
\hline$t_{1 / 2 \beta}(h)$ & $6.78 \pm 0.06$ & $8.21 \pm 0.37$ & $9.37 \pm 0.86$ \\
\hline $\mathrm{V}_{\mathrm{d} \text { (area) }}(\mathrm{L} / \mathrm{kg})$ & $1.36 \pm 0.06$ & - & - \\
\hline $\mathrm{Cl}_{\mathrm{B}}(\mathrm{L} / \mathrm{h} \cdot \mathrm{kg})$ & $0.139 \pm 0.007$ & - & - \\
\hline $\mathrm{C}_{\mathrm{o}}(\mu \mathrm{g} / \mathrm{mL})$ & $56.63 \pm 2.94$ & - & - \\
\hline $\mathrm{C}_{\max }(\mu \mathrm{g} / \mathrm{ml})$ & - & $4.47 \pm 0.16^{*}$ & $3.07 \pm 0.23^{*}$ \\
\hline $\mathrm{t}_{\max }(\mathrm{h})$ & - & $1.73 \pm 0.06^{*}$ & $3.34 \pm 0.21^{*}$ \\
\hline AUC $(\mu \mathrm{g} \cdot \mathrm{h} / \mathrm{mL})$ & $72.68 \pm 3.37$ & $53.33 \pm 1.80^{*}$ & $44.39 \pm 3.19^{*}$ \\
\hline MRT (h) & $7.97 \pm 0.12$ & $11.40 \pm 0.38^{*}$ & $13.93 \pm 0.67^{*}$ \\
\hline $\mathrm{F}_{\mathrm{abs}}(\%)$ & - & $73.38 \pm 2.47^{*}$ & $61.07 \pm 4.39^{*}$ \\
\hline $\mathrm{F}_{\text {rel }}(\%)$ & - & - & $83.23 \pm 5.99$ \\
\hline
\end{tabular}

Each value is the mean \pm SEM for six chickens; ${ }^{*}$ The marked values are significantly different $(\mathrm{P}<$ $0.05) ; \alpha, \beta=$ elimination rate constants; $\mathrm{K}_{\mathrm{a}}=$ first-order absorption rate constant; $\mathrm{t}_{1 / 2 \mathrm{a}}=$ absorption half-life; $t_{1 / 2 \alpha}, t_{1 / 2 \beta}=$ distribution and elimination half-lives; $C_{0}=$ initial plasma concentration; $\mathrm{C}_{\max }=$ maximal plasma concentration; $\mathrm{t}_{\max }=$ time to reach $\mathrm{C}_{\max } ; \mathrm{V}_{\mathrm{d} \text { (area) }}=$ apparent volume of distribution; $\mathrm{Cl}_{\mathrm{B}}=$ total body clearance; $\mathrm{AUC}=$ area under the curve; $\mathrm{MRT}=$ mean residence time; $\mathrm{F}_{\mathrm{abs}}=$ absolute bioavailability; $\mathrm{F}_{\text {rel }}=$ relative bioavailability

After i.v. administration, doxycycline was rapidly distributed in the body with a distribution half-life $\left(\mathrm{t}_{1 / 2 \alpha}\right)$ of $0.21 \pm 0.01 \mathrm{~h}$. The elimination half-life $\left(\mathrm{t}_{1 / 2 \beta}\right)$ of $6.78 \pm 0.06 \mathrm{~h}$ was relatively long and resulted from both a low total body clearance $\left(\mathrm{Cl}_{\mathrm{B}}\right)$ of $0.139 \pm 0.007 \mathrm{~L} / \mathrm{h} \cdot \mathrm{kg}$ and large volume of distribution $\left(\mathrm{V}_{\mathrm{d}(\text { area })}\right)$ of $1.36 \pm 0.06 \mathrm{~L} / \mathrm{kg}$.

Following oral administration to fasted chickens, doxycycline was quickly and extensively absorbed as shown by a mean absorption half-life $\left(\mathrm{t}_{1 / 2 \mathrm{a}}\right)$ of $0.39 \pm$ $0.03 \mathrm{~h}$, a maximal plasma concentration $\left(\mathrm{C}_{\max }\right)$ of $4.47 \pm 0.16 \mu \mathrm{g} / \mathrm{mL}$ and the time to reach the $\mathrm{C}_{\max }\left(\mathrm{t}_{\max }\right)$ of $1.73 \pm 0.06 \mathrm{~h}$. The distribution and the final elimination of the drug from the blood were slower after oral administration than fo llowing i.v. dosing. The values for $t_{1 / 2 \alpha}$ and $t_{1 / 2 \beta}$ were $3.61 \pm 0.43 \mathrm{~h}$ and $8.21 \pm$ $0.37 \mathrm{~h}$, respectively. Bioavailability $\left(\mathrm{F}_{\mathrm{abs}}\right)$ of doxycycline after oral administr ation to fasted chickens was $73.38 \pm 2.47 \%$.

After oral administration to nonfasted birds, the absorption of doxycycline was slower $\left(\mathrm{t}_{1 / 2 \mathrm{a}}=1.23 \pm 0.21 \mathrm{~h}, \mathrm{t}_{\max }=3.34 \pm 0.21 \mathrm{~h}\right)$ and less extensive $\left(\mathrm{C}_{\max }=\right.$ 
$3.07 \pm 0.23 \mu \mathrm{g} / \mathrm{mL})$. These values were significantly $(\mathrm{P}<0.05)$ different from those of fasted animals. Mainly due to the lower absorption rate, the calculated value for area under the concentration-time curve $(\mathrm{AUC}=44.39 \pm 3.19 \mu \mathrm{g} \cdot \mathrm{h} / \mathrm{mL})$ was also significantly different from the AUC of $55.33 \pm 1.80 \mu \mathrm{g} \cdot \mathrm{h} / \mathrm{mL}$ of fasted birds. The absolute bioavailability in nonfasted chickens was $61.07 \pm 4.39 \%$, whereas the relative bioavailability $\left(\mathrm{F}_{\text {rel }}\right)$ was calculated as $83.23 \pm 5.99 \%$.

\section{Discussion}

Doxycycline has been widely used in chickens to treat and prevent a var iety of bacterial infections. Data on the pharmacokinetics of the drug in this sp ecies are, however, scarce and there is no information on the possible effect of food on its pharmacokinetic profile.

The results obtained from the present study indicate that doxycycline is rapidly and extensively distributed and relatively slowly eliminated after i.v. a dministration. Our findings partly differ from those reported by Anadón et al. (1994) who found a similar distribution half-life $\left(\mathrm{t}_{1 / 2 \alpha}=0.23 \mathrm{~h}\right)$ but a faster elimination half-life $\left(\mathrm{t}_{1 / 2 \beta}=4.75 \mathrm{~h}\right)$, and a much lower volume of distribution $\left(\mathrm{V}_{\mathrm{d}(\mathrm{area})}=\right.$ $0.28 \mathrm{~L} / \mathrm{kg})$ and total body clearance $\left(\mathrm{Cl}_{\mathrm{B}}=0.04 \mathrm{~L} / \mathrm{h} \cdot \mathrm{kg}\right)$, respectively. Our data are, however, in good agreement with those found by Santos et al. (1996) in 6-weekold turkeys $\left(\mathrm{t}_{1 / 2 \beta}=7.90 \mathrm{~h} ; \mathrm{V}_{\mathrm{d}(\text { area })}=1.26 \mathrm{~L} / \mathrm{kg} ; \mathrm{Cl}_{\mathrm{B}}=0.11 \mathrm{~L} / \mathrm{h} \cdot \mathrm{kg}\right)$ or by Dorrestein et al. (1991) in pigeons $\left(\mathrm{t}_{1 / 2 \beta}=6.3 \mathrm{~h}\right)$. Similar results were also reported by Riond et al. (1990) for dogs $\left(\mathrm{t}_{1 / 2 \beta}=6.99 \mathrm{~h} ; \mathrm{V}_{\mathrm{d}(\text { area })}=1.01 \mathrm{~L} / \mathrm{kg} ; \mathrm{Cl}_{\mathrm{B}}=0.10 \mathrm{~L} / \mathrm{h} \cdot \mathrm{kg}\right)$.

After oral administration of doxycycline to fasted chickens, the drug was found to be quite rapidly and extensively absorbed from the gastrointestinal tract, followed by a slower distribution and final elimination from the blood than after i.v. dosing. The $C_{\max }, t_{\max }$ and $t_{1 / 2 \beta}$ values found in our study differed markedly from those $\left(\mathrm{C}_{\max }: 54.58 \mu \mathrm{g} / \mathrm{mL}\right.$; $\left.\mathrm{t}_{\max }: 0.35 \mathrm{~h} ; \mathrm{t}_{1 / 2 \beta}: 6.03 \mathrm{~h}\right)$ reported by Anadón et al. (1994), who used, however, a dose of $20 \mathrm{mg} / \mathrm{kg}$ in their study. In 6-week-old fasted turkeys the $\mathrm{C}_{\max }$ and $\mathrm{t}_{\max }$ were reported to be $7.40 \mu \mathrm{g} / \mathrm{mL}$ and $2.80 \mathrm{~h}$ after a single oral dose of $20 \mathrm{mg} / \mathrm{kg}$ (Santos et al., 1996) or $2.22 \mu \mathrm{g} / \mathrm{mL}$ and $1.80 \mathrm{~h}$ following a single oral administration of $15 \mathrm{mg} / \mathrm{kg}$ (Küng and Wanner, 1994). The absolute bioavailability of $73.4 \%$ calculated in our experiment was higher than those found by Anadón et al. (1994) in chickens (41.3\%) or by Santos et al. (1996) and by Küng and Wanner (1994) in 6-week-old turkeys (37.0\% and $44.6 \%$, respectively).

The presence of food in the intestinal tract significantly decreased and e $\mathrm{x}$ tended the absorption of the drug in chickens, resulting in a lower oral bioavai 1ability (61.1\%). The relative bioavailability (fed/fasted) was $83.2 \%$. Thus, the $\mathrm{n} \mathrm{u}$ tritional status was seen to influence the bioavailability of doxycycline in chickens as well. The effect was, however, less pronounced than in turkeys (Santos et al., 
1996), where the relative bioavailability varied between $40-60 \%$, except for the 3 week-old birds which showed a relative bioavailability value of $83.7 \%$.

In conclusion, the results obtained in the present study confirm that dox ycycline has useful pharmacokinetic properties for oral use in chickens. The pre sence of food in the intestinal tract appears to have less influence on the bioavai 1ability of the drug in this species than in turkeys.

\section{References}

Anadón, A., Martinez-Larranaga, M. R., Diaz, M. J., Bringas, P., Fernandez, M. C., FernandezCruz, M. L., Iturbe, J. and Martinez, M. A. (1994): Pharmacokinetics of doxycycline in broiler chickens. Avian Pathol. 23, 79-90.

Aronson, A. L. (1980): Pharmacotherapeutics of the newer tetracyclines. JAVMA 176, 1061-1068.

Dorrestein, G. M., Bruijne, J. J. D. and Vulto, A. (1991): Bioavailability of doxycycline injectables in pigeons. Acta Vet. Scand. 87 (Suppl.) 291-292.

Küng, K. and Wanner, M. (1994): Pharmakokinetik von Doxycycline bei Puten und Vergleich der Futter und Trinkwassermedikation. Arch. Geflügelk. 58, 84-88.

Meijer, L. A., Ceyssens, K. G. F., de Greve, B. I. J. A. C. and de Bruijn, W. (1993): Pharmacokinetics and bioavailability of doxycycline hyclate after oral administration in calves. Vet. Quarterly 15, 1-5.

Riond, I.-L., Vaden, S. L. and Riviere, J. E. (1990): Comparative pharmacokinetics of doxycycline in cats and dogs. J. Vet. Pharmacol. Therap. 13, 415-424.

Santos, M. D. F., Vermeersch, H., Remon, J. P., Schelkens, M., De Backer, P., Van Bree, H. I. I., Ducatelle, R. and Haesebrouck, F. (1996): Pharmacokinetics and bioavailability of doxycycline in turkeys. J. Vet. Pharmacol. Therap. 19, 274-280.

Santos, M. D. F., Vermeersch, H., Remon, J. P., Schelkens, M., De Backer, P., Ducatelle, R. and Haesebrouck, F. (1997): Administration of doxycycline hydrochloride via drinking water to turkeys under laboratory and field conditions. Poultry Sci. 76, 1342-1348.

Shaw, D. H. and Rubin, S. I. (1986): Pharmacologic activity of doxycycline. JAVMA 189, 808-810.

Várkonyi, P. (1983): A calculator package for pharmacokinetic application. Comp. Prog. Biomed. $17,277-282$.

Welling, P. G., Koch, P. A. and Curtis, C. L. (1977): Bioavailability of tetracycline and doxycycline in fasted and nonfasted subjects. Antimicrob. Agents Chemother. 11, 462-469. 